\title{
Syringoma, hormone receptors and associated endocrinopathies. Are they clinically relevant?
}

\section{Ayse Tülin Mansur ${ }^{1}$, Saime Ramadan²}

\author{
${ }^{1}$ Department of Dermatology, Baskent University Istanbul Hospital, Istanbul, Turkey, ${ }^{2}$ Department of Pathology, Baskent \\ University Istanbul Hospital, Istanbul, Turkey
}

Corresponding author: Dr. Ayse Tülin Mansur, E-mail: tulinmansur@gmail.com

\begin{abstract}
Syringomas are benign eccrine sweat gland tumors characterized by skin-colored or slightly yellowish papules. The lesions are predominantly located on the face, neck, and trunk, while vulvar involvement is relatively rare. There are some reported cases of syringomas manifesting lesional estrogen and/or progesterone receptor positivity. On the other hand, syringomas associated with endocrinopathies have infrequently been reported. We describe a 19-year-old female patient with asymptomatic skin coloured papules on both labia majora and pubis, present for 6 years. As polycystic ovary syndrome was diagnosed 4 years ago, she had been under treatment with a combination of cyproterone acetate and ethinyl estradiol for the past 2 years. Clinical, dermatoscopic, and histopathologic findings of the lesions were consistent with syringoma. Immunohistochemical stainings for estrogen and progesterone receptors were negative. To the best of our knowledge, there has been no previously reported case of vulvar syringoma associated with polycystic ovary syndrome. Hereby, we review the association of endocrinopathies with syringomas, together with the presence and clinical importance of hormone receptor positivity in syringoma lesions.
\end{abstract}

Key words: Syringoma; Vulvar; Estrogen receptor; Progesterone receptor; Endocrinopathy

\section{INTRODUCTION}

Syringomas are benign neoplasms of the intraepidermal portion of the eccrine sweat ducts, seen mainly in women and characterized by skin-coloured or slightly yellowish papules. The etiopathogenesis of syringomas is not clear yet, but hormonal influences have been suspected [1]. There are some reported cases of syringomas manifesting lesional estrogen receptor (ER) and progesterone receptor (PR) positivity [1-4]. Herein, we present a case of vulvar syringoma (VS) and in this context, we review the endocrinological abnormalities associated with syringomas, reported up to date, and discuss the clinical importance of lesional ER and PR positivity.

\section{CASE REPORT}

A 19-year-old female patient presented to the dermatology outpatient clinic for evaluation of asymptomatic genital papules developed 6 years ago, with the onset of puberty. The lesions had been increasing in size and extent since then. Medical history revealed polycystic ovary syndrome diagnosed 4 years ago, and she had been under treatment with a combination of $2 \mathrm{mg}$ cyproterone acetate and $0.035 \mathrm{mg}$ ethinyl estradiol for the past 2 years. No other members of her family had similar skin lesions.

On dermatological examination, symmetrical skincoloured or slightly hyperpigmented papules of approximately $0.5 \mathrm{~cm}$ in diameter were observed on both labia majora and pubis. On the lower areas of the labia, the lesions formed thick plaques with smooth surfaces. She had a few papules on her axillary vaults clinically similar to genital ones. Papulopustular acne lesions were seen on the face and back, and facial hirsutism was evident on the chin and sideburns.

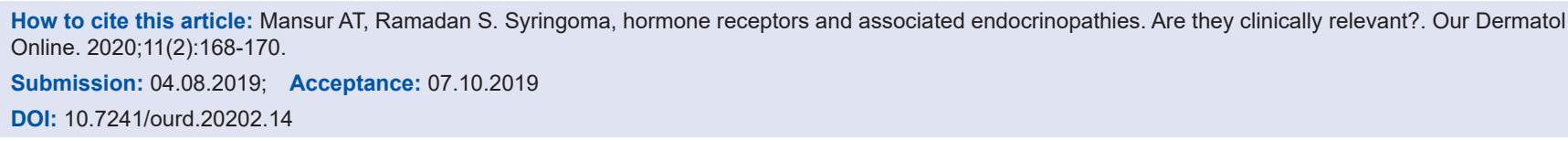


Dermatoscopic examination of the vulvar lesions showed white-yellowish, homogenous, round, shiny clods grouped together on a pink background.

Histopathological examination revealed interconnecting epithelial strands and cystic ducts dispersed in a fibrous stroma within the upper dermis (Fig. la). The ducts were lined by two layers of flattened cuboidal cells. Some of the ducts were associated with an epithelial strand, giving rise to the characteristic tadpole appearance (Fig. lb). No mitotic figure or atypia was seen throughout the tumor. Immunohistochemical staining showed luminal staining with carcinoembryonic antigen (CEA)

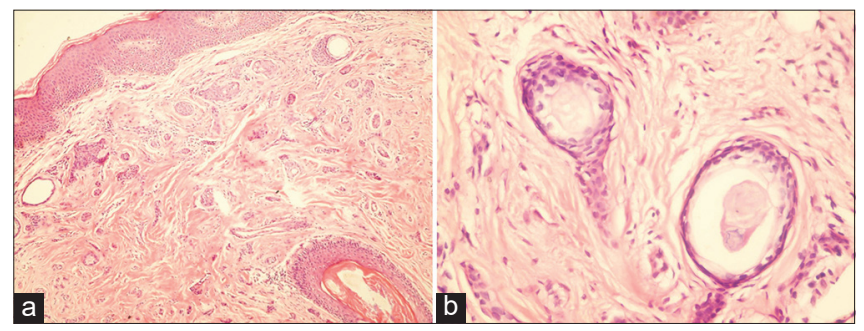

Figure 1: (a) Epithelial strands and small cysts in a fibrous stroma. H\&E x40. (b)Characteristic tadpole appearance. H\&E x400.

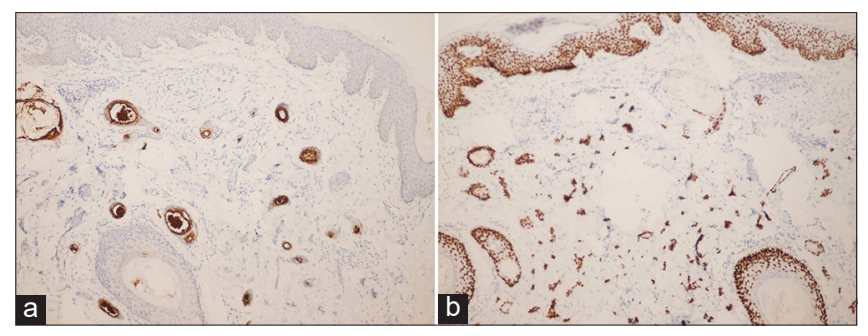

Figure 2: (a)Luminal staining with CEA. CEA immunostain $x 100$. (b) Positive staining with p63. p63 immunostain x100.
(Fig. 2a). Smooth muscle actin (SMA) and p63 were positive (Fig. 2b). Ki-67 proliferation index was very low (1\%). Stainings for ER and PR were negative. Histomorphologic and immunohistochemical findings were compatible with syringoma.

\section{DISCUSSION}

Vulvar syringomas may exclusively affect the genital area, or they may be present with extragenital syringomas. Adolescence is the most common time of onset for VS. The severity of pruritus and the size of the lesions may increase during menstruation, pregnancy and use of oral contraceptives. Based on these findings, it has been suggested that the growth of the syringomas including VS are at least partially under control of hormones [1-4]. The first authors pointed to this issue are Swanson et al, who investigated immunoreactivity for ER protein in sweat gland tumors [2]. In their study, syringomas (7 cases) yielded negative results. Later on, Wallace and Smoller showed nuclear and cytoplasmic staining with ER in 1/9, and with PR in 8/9 of syringomas [3]. Since then in some studies, ER and/or PR were detected in syringomas, but some other studies did not get the same result as in our case [1,4-11] (Tab. I) . As seen in Table 1, PR positivity is more frequently reported, while ER is rarely found. Since PR nuclear staining was also observed in eccrine sweat glands [3], it may not be surprising that syringomas can manifest PR positivity. Table 1 shows that the only associated endocrinopathy was diabetes mellitus (DM). In two of the cases with DM, syringomas showed clear cell type, while in others the histopathological types

Table 1: Reports of syringomas with estrogen and progesterone receptor studies

\begin{tabular}{|c|c|c|c|c|c|c|c|}
\hline $\begin{array}{l}\text { Report } \\
\text { (author/year) }\end{array}$ & $\begin{array}{l}\text { Number } \\
\text { of Ps }\end{array}$ & $\begin{array}{c}\text { Age/ } \\
\text { Gender }\end{array}$ & $\begin{array}{l}\text { Vulvar } \\
\text { lesions }\end{array}$ & $\begin{array}{l}\text { Associated } \\
\text { endocrinopathy }\end{array}$ & $\begin{array}{c}\text { ER } \\
\text { positivity }\end{array}$ & $\begin{array}{c}\text { PR } \\
\text { positivity }\end{array}$ & $\begin{array}{l}\text { Type of } \\
\text { syringoma }\end{array}$ \\
\hline Swanson, 1991 & 7 & NA & NA & NA & - & NA & NA \\
\hline $\begin{array}{l}\text { Wallace \& } \\
\text { Smoller, } 1995\end{array}$ & 9 & $\begin{array}{c}16-68 \\
2 \mathrm{M}, 7 \mathrm{~F}\end{array}$ & - & NA & $+(1 / 9)$ & $+(8 / 9)$ & $\begin{array}{l}5 \text { multiple, } \\
3 \text { single }\end{array}$ \\
\hline Yorganci, 2000 & 1 & $27, \mathrm{~F}$ & + & NA & NA & + & Multiple \\
\hline Trager, 1999 & 1 & $8, \mathrm{~F}$ & + & NA & - & - & Localized \\
\hline $\begin{array}{l}\text { Timpanidis, } \\
2003\end{array}$ & 1 & $55, \mathrm{M}$ & - & DM & - & + & $\begin{array}{l}\mathrm{CC} \text { and } \\
\text { Eruptive }\end{array}$ \\
\hline Huang Y, 2003 & 18 & $21-60 / F$ & $18 / 18$ & NA & $-(15 / 18)$ & $-(15 / 18)$ & Multiple \\
\hline Fathy, 2005 & 25 & $\begin{array}{l}11-36 \\
20 F, 5 M\end{array}$ & $2 / 25$ & 1/25, DM & $-(25 / 25)$ & $+(23 / 25)$ & $\begin{array}{l}13 \text { localized, } 12 \\
\text { eruptive (1 CC) }\end{array}$ \\
\hline Kariya, 2005 & 3 & NA & NA & NA & $+(1 / 3)$ & $+(3 / 3)$ & NA \\
\hline Lee, 2007 & 61 & $\begin{array}{c}10-72 \\
53 \mathrm{~F}, 8 \mathrm{M}\end{array}$ & $+(8 / 53)$ & 1/61, DM & $-(56 / 56)$ & $-(56 / 56)$ & $\begin{array}{l}8 \text { generalized, } \\
53 \text { localized }\end{array}$ \\
\hline $\begin{array}{l}\text { Garrido-Ruiz, } \\
2008\end{array}$ & 1 & $31, \mathrm{M}$ & - & - & - & - & Eruptive \\
\hline Akoğlu, 2013 & 1 & $40 / F$ & + & DM & - & - & Localized \\
\hline
\end{tabular}

P: patient, F: female, M: male, ER: Estrogen receptor, PR: progesterone receptor, DM: diabetes mellitus, CC: clear cell, NA: not available 
Table 2: Reports of non-clear cell syringomas associated with endocrinopathy

\begin{tabular}{lcll}
\hline $\begin{array}{l}\text { Report } \\
\text { (author/year) }\end{array}$ & $\begin{array}{c}\text { Age/ } \\
\text { Gender }\end{array}$ & $\begin{array}{l}\text { Type of } \\
\text { syringoma }\end{array}$ & $\begin{array}{l}\text { Associated } \\
\text { endocrinopathy }\end{array}$ \\
\hline $\begin{array}{l}\text { Aliagaoğlu, } \\
2004\end{array}$ & $34 / \mathrm{M}$ & $\begin{array}{l}\text { Unilateral } \\
\text { facial }\end{array}$ & Hyperthyroidism \\
Polat, 2010 & $45 / \mathrm{F}$ & $\begin{array}{l}\text { Eruptive } \\
\text { Vulvar }\end{array}$ & Hyperthyroidism \\
Akoğlu, 2013 & $40 / \mathrm{F}$ & DM \\
Avcı, 2016 & $59 / \mathrm{M}$ & Eruptive & Hyperthyroidism \\
\hline
\end{tabular}

F: female, M: male, DM: diabetes mellitus

were not mentioned. The cases associated with DM were either PR positive or negative, indicating that hormone receptor positivity and DM presence seems to be unrelated.

Reports of syringomas associated with endocrinopathy are limited in number. Association with DM has mostly been reported in eruptive and clear cell variants of syringomas. It has even been suggested that multiple or eruptive clear cell syringomas may be considered as a cutaneous marker for DM [6]. Clear cell syringoma is characterized by clear cells with a vacuolated cytoplasm containing glycogen, besides other typical histological findings of syringomas. A deficiency or decreased activity of phosphorylase due to raised glucose level was suggested for glycogen accumulation in clear cells [6].

Endocrinopathies associated with non-clear cell syringomas are scant and listed in Table 2 [4,12-14]. It is not known whether the treatment of associated disorder affects the regression or clearance of syringomas in the patients with DM or other endocrinopathies.

To the best of our knowledge, there has been no reported case of VS associated with polycystic ovary syndrome. It is not clear yet whether this is merely a coincidence or not.

Studies up to date have not revealed a definitive association between syringomas and hormonal effects. The lesions might not be under hormone control, or regulated by hormones through some mechanisms other than hormonal receptors.

\section{Consent}

The examination of the patient was conducted according to the Declaration of Helsinki principles.

\section{REFERENCES}

1. Huang YH, Chuang YH, Kuo TT, Yang LC, Hong HS. Vulvar syringoma: a clinicopathologic and immunohistologic study of 18 patients and results of treatment. J Am Acad Dermatol. 2003;48:735-9.

2. Swanson PE, Mazoujian G, Mills SE, Campbell RJ, Wick MR. Immunoreactivity for estrogen receptor protein in sweat gland tumors. Am J Surg Pathol. 1991;15:835-41.

3. Wallace ML, Smoller BR. Progesterone receptor positivity supports hormonal control of syringomas. J Cutan Pathol. 1995:22:442-5.

4. Akoglu G, Ibiloglu I, Durmazlar N. Vulvar nonclear cell syringoma associated with pruritus and diabetes mellitus. Case Rep Dermatol Med. 2013;2013:418794.

5. Trager JD, Silvers J, Reed JA, Scott RA. Neck and vulvar papules in an 8-year-old girl. Arch Dermatol. 1999;135:203-6.

6. Timpanidis PC, Lakhani SR, Groves RW. Progesterone receptorpositive eruptive syringoma associated with diabetes. J Am Acad Dermatol. 2003;48(5 Suppl):S103-4.

7. Fathy H, Abdel Aziz AM, Elhanbly S, El-Hawary AK, Amin MM. Is syringoma hormonally dependent? J Egypt wom Dermatol Soc. 2005;2:12-6.

8. Kariya Y, Moriya T, Suzuki T, Chiba M, Ishida K, Takeyama J, et al. Sex steroid hormon receptors in human skin appandage and its neoplasms. Endocrine Journal. 2005;52:317-25.

9. Lee JH, Chang JY, Lee KH. Syringoma: a clinicopathologic and immunohistologic study and results of treatment. Yonsei Med J. 2007;48:35-40.

10. Garrido-Ruiz MC, Enguita AB, Navas R, Polo I, Rodríguez Peralto JL. Eruptive syringoma developed over a waxing skin area. Am J Dermatopathol. 2008;30:377-80.

11. Yorganci A, Kale A, Dunder I, Ensari A, Sertcelik A. Vulvar syringoma showing progesterone receptor positivity. BJOG. 2000;107:292-4.

12. Aliagaoglu C, Atasoy M, Yildirim U, Balik O, Koca T, Erdem T. Unilateral syringoma of the face associated with hyperthyroidism. J Dermatol. 2004;31:828-30.

13. Polat M, Pelitli A, Oztaş P, Unal T, Alli N. Eruptive syringoma associated with hyperthyroidism. Skinmed. 2010;8:124-5.

14. Avcı A, Altınor SȘ, Özyurt K, Atasoy M, Ulaş Y, Avcı D, et al. An eruptive syringoma case associated with hyperthyroidism. J Turk Acad Dermatol. 2016;10:16102c8.

Copyright by Ayse Tülin Mansur, et al. This is an open-access article distributed under the terms of the Creative Commons Attribution License, which permits unrestricted use, distribution, and reproduction in any medium, provided the original author and source are credited.

Source of Support: Nil, Conflict of Interest: None declared. 